\title{
CLINICAL PROFILE OF MULTIPLE MYELOMA IN A TERTIARY CARE CENTER FROM NORTH EAST INDIA
}

\author{
Ajit Kumar Pegu', Anupam Dutta 2 , Vineet Kumar Todi ${ }^{3}$ \\ ${ }^{1}$ Associate Professor, Department of Medicine, Assam Medical College and Hospital. \\ ${ }^{2}$ Assistant Professor, Department of Medicine, Assam Medical College and Hospital. \\ ${ }^{3}$ Post Graduate Trainee, Department of Medicine, Assam Medical College and Hospital.
}

\begin{abstract}
Multiple Myeloma is a neoplastic disease of the plasma cells characterized by clonal proliferation of terminally differentiated B lymphoid cells, which accumulate in bone marrow and produce a monoclonal protein (Immunoglobulin), usually IgG or IgA, often referred to as $\mathrm{M}$ or myeloma protein.
\end{abstract}

\section{AIMS AND OBJECTIVES \\ Our study aims to describe the common clinical and laboratory features, stages and outcome of patients with Multiple Myeloma coming to a Tertiary Care Center in North East India.}

\section{MATERIALS AND METHODS}

Newly diagnosed and previously diagnosed untreated patients of MM coming to Assam Medical College over a period of one year from June 2013 to May 2014 were randomly included in this prospective observational study. Diagnosis was confirmed by the 2009 updated criteria of International Myeloma Working Group and clinical features, laboratory findings and outcome were studied.

\section{RESULTS AND OBSERVATIONS}

44 Multiple myeloma mostly from $5^{\text {th }}$ and $6^{\text {th }}$ decade with the age varying from 38 to 82 and a mean age of 57.7 years (SD 10.29); $27(61 \%)$ patients were male and 17 (39\%) were females with a male-to-female ratio of 1.6:1; 38 (86\%) presented with backache and other bone pains, 35(80\%) had generalized weakness and easy fatigability, 13 (30\%) had symptoms of spinal cord compression, $14(32 \%)$ had fever. On examination 37 (84\%) had pallor, 34 (77\%) had bony tenderness, 14 (32\%) had paraplegia; 40 (91\%) cases revealed positive $\mathrm{M}$ Band by serum protein electrophoresis. In rest of the 4 cases, band was determined by immunofixation method. Urinary Bence-Jones protein was estimated in 28 out of 44 patients and of them 4 (14\%) were positive; 40 ( $91 \%)$ had radiologically detectable abnormalities; 35 (80\%) had lytic lesions, 17 (39\%) had pathological fractures, 21 (48\%) had generalized osteoporosis and only $4(9 \%)$ had normal skeletal survey. Out of 35 cases of lytic lesions, most frequent area was spine in 25 (71\%); 7 (16\%) cases were found to be in stage I, 20 (45\%) were found to be in stage II and 17 (39\%) were in stage III.

\section{CONCLUSION}

We conclude that though most patients were in sixth decade, but we got significant involvement in younger age group. Bone pain, mostly low backache was the most common presenting symptom along with fatigue and weakness. Majority of patients were in higher stages (ISS II, III) at the time of diagnosis and severe anaemia, lytic lesions, pathological fractures and renal insufficiency were most observations in these patients in higher stages.

\section{KEYWORDS}

Multiple Myeloma, Haematological Malignancies, M Band, Myeloma Protein, Urinary Bence-Jones Protein.

HOW TO CITE THIS ARTICLE: Pegu AK, Dutta A, Todi VK. Clinical profile of multiple myeloma in a tertiary care center from North East India. J. Evolution Med. Dent. Sci. 2016;5(52):3382-3385, DOI: 10.14260/jemds/2016/781

\section{INTRODUCTION}

Multiple Myeloma has most likely been present for thousands of years, but first well-documented case was a patient, Sarah Newbury, described by Samuel Solly in $1844 .{ }^{1}$ This 39 -yearold women developed fatigue and bone pain from multiple fractures. The best known case of MM was that of Thomas Alexander McBean, "a highly respectable tradesman," 45 years of age. He developed fatigue and had noted that his "body linen was stiffened by his urine."

Financial or Other, Competing Interest: None.

Submission 11-05-2016, Peer Review 07-06-2016,

Acceptance 13-06-2016, Published 29-06-2016.

Corresponding Author:

Dr. Anupam Dutta,

Revti House, Purnananda Road,

Shantipara,

Dibrugarh-786001,

Assam.

E-mail: dranupamdutta@yahoo.com,dranupamdutta80@gmail.com DOI: $10.14260 /$ jemds $/ 2016 / 781$
For two years before his death on January 1, 1846, he complained of severe recurrent bone pains on multiple occasions. ${ }^{2}$

Multiple Myeloma is a neoplastic disease of the plasma cells characterized by clonal proliferation of terminally differentiated B lymphoid cells, which accumulate in bone marrow and produce a monoclonal protein (Immunoglobulin), usually IgG or IgA, often referred to as M or myeloma protein. Multiple Myeloma comprises $10 \%$ of all haematological malignancies and $1 \%$ of all neoplastic disorders with usual age of presentation in $6^{\text {th }}$ and 7 th decade of life. Exact incidence in India is not known, but data from 6 population based cancer registries (Covering $<0.3 \%$ ) shows 0.3 to 1.9 per $1,00,000$ men and 0.4 to 1.3 per $1,00,000$ women, highest in Delhi. ${ }^{3}$

\section{AIMS AND OBJECTIVES}

In India clinical study of Multiple myeloma is very much limited, especially in North East India. 
Our study aims to describe the common clinical and laboratory features, stages and outcome of patients with Multiple Myeloma coming to a tertiary care center in North East India.

\section{MATERIALS AND METHODS}

Newly diagnosed and previously diagnosed untreated patients of MM coming to Assam Medical College over a period of one year from June 2013 to May 2014 were randomly included in this prospective observational study. Diagnosis was confirmed by the 2009 updated criteria of International Myeloma Working Group. ${ }^{4}$ (Table No. 1). Patients with monoclonal gammopathy of undetermined significance, other coexisting malignancy, non-secretory myeloma, solitary plasmacytoma of bone and previously diagnosed case of MM under treatment were excluded from the study. Informed consent and ethical clearance were taken. Patients were evaluated on the basis of proper history, clinical examination and laboratory and imaging investigations. Evidence of end organ damage was assessed by the ROTI criteria. ${ }^{5}$ Staging of the cases was done on the basis of International Staging System (ISS).

\begin{tabular}{|c|c|c|}
\hline \multicolumn{3}{|c|}{$\begin{array}{c}\text { Diagnostic criteria for Symptomatic Multiple Myeloma by } \\
\text { International Multiple Myeloma Working Group 2003, } \\
\text { Updated in } 2009\end{array}$} \\
\hline 1 & \multicolumn{2}{|r|}{ Monoclonal protein present in serum and/or urine } \\
\hline 2 & \multicolumn{2}{|r|}{ Clonal bone marrow plasma cell or plasmacytoma } \\
\hline \multicolumn{3}{|r|}{ Related organ or tissue impairment (ROTI) } \\
\hline \multirow{4}{*}{3} & C & $\begin{array}{c}\text { Hypercalcaemia (Corrected calcium }>2.75 \\
\text { mmol/L) }\end{array}$ \\
\hline & $\mathrm{R}$ & Renal insufficiency attributable to myeloma \\
\hline & A & Anaemia (Haemoglobin $<10 \mathrm{~g} / \mathrm{dL}$ ) \\
\hline & B & $\begin{array}{l}\text { Bone lesions (Lytic lesions or osteoporosis with } \\
\text { compression fractures) }\end{array}$ \\
\hline \multicolumn{3}{|r|}{$\begin{array}{l}\text { Table 1: Diagnostic Criteria for } \\
\text { Symptomatic Multiple Myeloma }\end{array}$} \\
\hline
\end{tabular}

All the data was entered into Microsoft Excel 2010 spreadsheet and analysed by GraphPad Prism Version 6.05 software. Various data were correlated with ISS stage using the contingency coefficient analysis (Cross tabs procedure). The significance of study parameters between the three ISS stage was assessed using Freeman-Halton extension of Fisher's exact test. Significance was assessed at 5\% level of significance $(\mathrm{p}<0.05)$.

\section{RESULTS AND OBSERVATIONS}

$44 \mathrm{MM}$ cases were included in the study with 5 patients from 31 to 40 years, 7 from 41 to 50 years, 16 from 51 to 60 years, 14 from 61 to 70 years and 2 cases above 71 years. The age varied from 38 to 82 with a mean age of 57.7 years (SD 10.29). 27 (61\%) patients were male and 17 (39\%) were females with a male-to-female ratio of 1.6:1 (Table No. 2).

\begin{tabular}{|c|c|c|}
\hline Parameters & Patients $(n=44)$ & Percentage \\
\hline \multicolumn{3}{|l|}{ Age Wise Distribution } \\
\hline $31-40$ years & 5 & $11.4 \%$ \\
\hline 41-50 years & 7 & $15.9 \%$ \\
\hline 51-60 years & 16 & $36.4 \%$ \\
\hline $61-70$ years & 14 & $31.8 \%$ \\
\hline$>70$ years & 2 & $4.5 \%$ \\
\hline \multicolumn{3}{|l|}{ Sex } \\
\hline Male & 27 & $61 \%$ \\
\hline Female & 17 & $39 \%$ \\
\hline \multicolumn{3}{|c|}{ Table 2: Demographic Profile of Our Patients } \\
\hline
\end{tabular}

$38(86 \%)$ patients presented with backache and other bone pains which was the most common symptom; 35 (80\%) patients had generalized weakness and easy fatigability, 13 (30\%) had symptoms of spinal cord compression, 14 (32\%) had fever, 10 (23\%) had cough, 4 (9\%) had burning micturition and urgency, 8 (18\%) had bleeding manifestation, $16(36 \%)$ had constipation, 12 (27\%) had polydipsia, $6(14 \%)$ had nausea and vomiting, 3 had somnolence and 2 patients had confusion (Table No. 3).

\begin{tabular}{|c|c|c|}
\hline Parameters & $\begin{array}{l}\text { Patients } \\
(n=44)\end{array}$ & Percentage \\
\hline \multicolumn{3}{|l|}{ Symptoms } \\
\hline $\begin{array}{l}\text { Backache and other bone } \\
\text { pains }\end{array}$ & 38 & $86 \%$ \\
\hline Generalized weakness & 35 & $80 \%$ \\
\hline $\begin{array}{c}\text { Symptoms of spinal cord } \\
\text { compression }\end{array}$ & 13 & $30 \%$ \\
\hline Fever & 14 & $32 \%$ \\
\hline Cough & 10 & $23 \%$ \\
\hline $\begin{array}{l}\text { Burning micturition and } \\
\text { urgency }\end{array}$ & 4 & $9 \%$ \\
\hline bleeding manifestation & 8 & $18 \%$ \\
\hline Constipation & 16 & $36 \%$ \\
\hline Polydipsia & 12 & $27 \%$ \\
\hline Nausea and vomiting & 6 & $14 \%$ \\
\hline Somnolence & 3 & $6.8 \%$ \\
\hline Confusion & 2 & $4.5 \%$ \\
\hline \multicolumn{3}{|l|}{ Signs } \\
\hline Pallor & 37 & $84 \%$ \\
\hline Bony tenderness & 34 & $77 \%$ \\
\hline Paraplegia & 14 & $32 \%$ \\
\hline Oedema & 6 & $14 \%$ \\
\hline Splenomegaly & 2 & $4.5 \%$ \\
\hline Hepatomegaly & 1 & $2.3 \%$ \\
\hline \multicolumn{3}{|l|}{ Laboratory results } \\
\hline $\begin{array}{l}\text { Positive M Band by serum } \\
\text { protein electrophoresis }\end{array}$ & 40 & $91 \%$ \\
\hline Urinary Bence-Jones protein & $\begin{array}{c}4(28 \\
\text { tested })\end{array}$ & $14 \%$ \\
\hline \multicolumn{3}{|l|}{ Skeletal involvement } \\
\hline $\begin{array}{c}\text { Radiologically detectable } \\
\text { abnormalities }\end{array}$ & 40 & $91 \%$ \\
\hline Lytic lesions & 35 & $80 \%$ \\
\hline Spine & 25 & $71 \%$ \\
\hline Lumbosacral spine & 24 & $69 \%$ \\
\hline Thoracic spine & 12 & $34 \%$ \\
\hline Skull & 23 & $66 \%$ \\
\hline Ribs & 15 & $43 \%$ \\
\hline Long bones in and & 12 & $34 \%$ \\
\hline Pelvis in & 8 & $23 \%$ \\
\hline Clavicle in & 4 & $11 \%$ \\
\hline Scapula & 3 & $8.5 \%$ \\
\hline Pathological fractures & 17 & $39 \%$ \\
\hline Vertebra & 14 & $87 \%$ \\
\hline Ribs & 7 & $44 \%$ \\
\hline Long bones (Femur) & 2 & $12.5 \%$ \\
\hline Generalized osteoporosis & 21 & $48 \%$ \\
\hline Normal skeletal survey & 4 & $9 \%$ \\
\hline \multicolumn{3}{|c|}{ Table 3: Clinical Presentation } \\
\hline
\end{tabular}

On examination 37 (84\%) patients had pallor and 34 (77\%) patients had bony tenderness; 14 (32\%) patients presented with paraplegia; 6 (14\%) patients had oedema. 
Splenomegaly and hepatomegaly were seen in 2 and 1 patient respectively; 40 (91\%) cases revealed positive M Band by serum protein electrophoresis. In rest of the 4 cases, band was determined by immunofixation method. Urinary BenceJones protein was estimated in 28 out of 44 patients and of them 4 (14\%) were positive. Immunofixation electrophoresis (IFE) was done on 8 patients of whom 6 had IgG, 1 had IgA and 1 had light chain myeloma.

40 (91\%) had radiologically detectable abnormalities; 35 (80\%) had lytic lesions, 17 (39\%) had pathological fractures, $21(48 \%)$ had generalized osteoporosis and only 4 (9\%) had normal skeletal survey. Out of 35 cases of lytic lesions, most frequent area was spine in $25(71 \%)$ followed by skull in 23 (66\%), ribs in 15 (43\%), long bones in 12 (34\%), pelvis in 8 $(23 \%)$, clavicle in $4(11 \%)$ and scapula in $3(8.5 \%)$ cases. In 24 (69\%) cases, lytic lesion were seen in lumbosacral spine and in $12(34 \%)$ they were seen in thoracic spine. Femur was the most common long bone to be involved with $8(23 \%)$ followed by humerus in $3(8 \%)$ and radius in $1(3 \%)$. Out of 17 cases of pathological fractures $14(87 \%)$ were in the vertebra, 7 (44\%) were in ribs and 2 (12.5\%) were in long bones (Femur).

The mean $\mathrm{Hg}$ was $7.12 \mathrm{gm} / \mathrm{dL} ; 18$ (41\%) has severe anaemia with $\mathrm{Hg}<7 \mathrm{gm} / \mathrm{dL}, 23$ (52\%) had moderate anaemia with $\mathrm{Hg}$ between 7 to $10 \mathrm{gm} / \mathrm{dL}$ and 3 had mild anaemia with Hg between 10 to $12 \mathrm{gm} / \mathrm{dL}$; 4 cases had leucopenia with total count $<4000 /$ cumm and 5 had leucocytosis with total count $>12,000 /$ cumm (Mean total count was 8002). The mean platelet count was 1.6 lack and mean ESR $124.8 \mathrm{~mm} \mathrm{AEFH.}$ Mean serum creatinine was $1.66 \mathrm{mg} / \mathrm{dL}$ with 9 (20\%) cases having serum creatinine $>2 \mathrm{mg} / \mathrm{dL}$. Mean corrected serum calcium was $10.37 \mathrm{mg} / \mathrm{dL}$ with $10(23 \%)$ cases having raised serum calcium >11 mg/dL; 29 (66\%) had hypoalbuminemia; $26(59 \%)$ had serum globulin $>3.5$ to 5.5 and 17 (39\%) had $>5.5 \mathrm{gm} / \mathrm{dL} ; 11$ (25\%) had serum beta-2 microglobulin level $<3.5 \mathrm{mg} / \mathrm{L}, 16$ (36\%) from 3.6 to $5.5 \mathrm{mg} / \mathrm{L}$ and 17 (39\%) had $>5.5 \mathrm{mg} / \mathrm{L}$.

Bone marrow study showed that out of 44 cases, $6(14 \%)$ cases had bone marrow plasma cell concentration between $<20 \%, 8(18 \%)$ cases between 20 to $<30 \%, 11(25 \%)$ cases between 30 to $<40 \%, 10(22 \%)$ cases between 40 to $<50 \%$ and $9(20 \%)$ cases above $50 \%$. The mean bone marrow plasma cell concentration was $37 \%$.

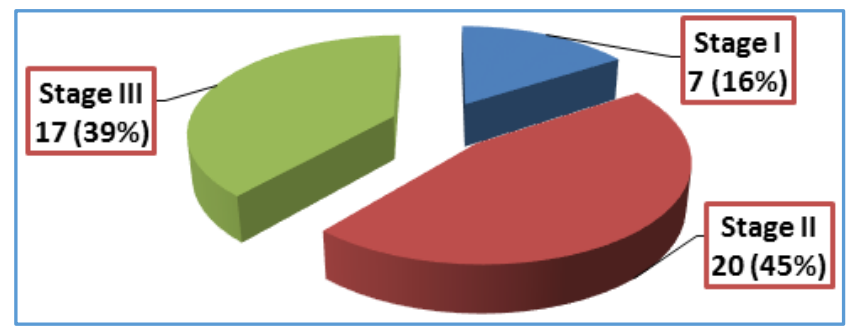

Fig. 1: Stages of Presentation

$7(16 \%)$ cases were found to be in stage I, 20 (45\%) were found to be in stage II and 17 (39\%) were in stage III. One (1) out of $7(14.29 \%)$ in stage I, 6 out of $20(30 \%)$ in stage II and 11 out of 17 (64.7\%) in stage III were having haemoglobin $<7$ $\mathrm{gm} / \mathrm{dL}$. There was a trend towards higher percentage of cases having CRP $>6 \mathrm{mg} / \mathrm{L}$ with higher ISS stage, but this correlation was statistically insignificant $(p=0.42)$. A statistically significant $(\mathrm{p}=0.02)$ correlation of serum LDH with stage of the disease was found showing serum LDH (>285/IU/L) in 0\%,
$40 \%, 58.8 \%$ of patients with ISS-I, II and III respectively. Serum creatinine $>/=2 \mathrm{mg} / \mathrm{dL}$ was observed in $0 \%, 10 \%$ and $41.2 \%$ of cases of ISS-I, II and III respectively $(p=0.029)$. Higher percentage of cases with high ISS stage had serum calcium $>11$ $\mathrm{mg} / \mathrm{dL}$, but it was found to be statistically insignificant $(\mathrm{p}=$ $0.186)$. Similar results were found with serum uric acid $(p=1)$.

Five (5) (71.43\%) cases of stage I, 18 (90\%) cases of stage II and 17 (100\%) cases of stage III had skeletal lesions, which was statistically significant ( $\mathrm{p}=0.07) ; 3(42.86 \%)$ of stage I, 16 (80\%) of stage II and $16(94.12 \%)$ cases of stage III had lytic lesion which was also statistically significant $(p=0.024)$. Statistically significant correlation also exists between pathological fracture and the ISS stage of disease $(p=0.004)$ as none, 6 (30\%) and 11 (64.7\%) of stage I, II and III respectively had pathological fractures. Association of generalized osteoporosis with the ISS stage was not statistically significant $(p=0.922)$. There exists significant correlation between the ISS stage and serum beta 2 microglobulin $>/=3.5(\mathrm{p}<0.001)$.

None, 16 (80\%) and 17 (100\%) cases of stage I, II and III respectively had serum beta 2 microglobulin $>/=3.5$. Similarly, there exists significant correlation between stages and serum albumin $<3.5(\mathrm{p}=0.002)$ as $1(14.29 \%)$ case of stage I, $13(65 \%)$ cases of stage II and $15(88.24 \%)$ cases of stage III had serum albumin $<3.5$. A statistically significant correlation also exists between bone marrow plasma cell (BMPC) $>/=33 \%$ and the ISS stage of the disease $(\mathrm{p}=0.002)$. In this study $14.29 \%, 55 \%$ and $88.24 \%$ cases in stage I, II and III respectively had BMPC $>/=33 \%$.

\section{DISCUSSION}

Diwan AG et al (2014). ${ }^{6}$ reported that sixth decade is the common age group with a mean of 62 years. Kyle RA et al (2003). ${ }^{5}$ reported that the mean age was 66 years with $2 \%$ younger than 40 and $38 \%$ older than 70 years. Kumar L et al (2006). ${ }^{7}$ reported that in India the median age is 55 years; 2 decades earlier than that in USA we found $5(11.4 \%)$ patients from 31 to 40 years and a mean age of 57.7 years. Madu AJ et al (2014). ${ }^{8}$ found male:female ratio $1.2: 1$ and Kumar L et al ${ }^{5}$ found 1.5:1. We also found a male:female ratio of 1.5:1.

Bone pain was reported by Diwan AG et al 6 in $85 \%$, Madhu $\mathrm{AJ}$ et $\mathrm{al}^{8}$ in $78.1 \%$, Rahman AAU et al $^{9}$ in $78 \%$ and Durie BGM et al ${ }^{10}$ in $58 \%$. We found them in $86.3 \%$. Riccardi A et al ${ }^{11}$ reported symptoms of spinal cord compression in 34\%, Dancaster CP et al 12 in $15 \%$, Madu AJ et al ${ }^{8}$ in $13.8 \%$ and Diwan $\mathrm{AG}$ et $\mathrm{al}^{6}$ in $10 \%$. In our study, symptoms of spinal cord compression was seen in $29.55 \%$.

Diwan AG et al ${ }^{6}$ found anaemia in $100 \%$ and Rahman AAU et al $^{9}$ found mean haemoglobin of 7.56. We found $93 \%$ anaemia and mean haemoglobin of $7.12 \mathrm{gm} / \mathrm{dL}$. However, Grepp PR et $\mathrm{al}^{13}$, Blade J et $\mathrm{al}^{14}$ and Durie BGM et $\mathrm{al}^{10}$ showed mean haemoglobin level $>8.5 \mathrm{gm} / \mathrm{dL}$.

Madu AJ et al8, Diwan AG et al6, Kumar L et al 7 and Bade J et $\mathrm{al}^{14}$ showed serum creatinine level $>2 \mathrm{mg} / \mathrm{dL}$ in $13.8 \%$, $30 \% ; 31.3 \%$ and $22.3 \%$ respectively, which was $20.45 \%$ in our study. Dimopoulos MA et al ${ }^{15}$, Li SD et al ${ }^{16}$, Kyle RA et al ${ }^{5}$ and Dancaster CP et al ${ }^{12}$ reported hypercalcaemia in $16 \%, 19.5 \%$, $13 \%$ and $22 \%$ respectively, whereas we found it in $22.73 \%$. Grepp PR et $\mathrm{al}^{13}$ and Madu AJ et $\mathrm{al}^{8}$ found mean serum beta 2 microglobulin of 3.8 and $4 \mathrm{mg} / \mathrm{L}$, whereas we found it to be $4.92 \mathrm{mg} / \mathrm{L}$.

Kyle RA et al ${ }^{5}$, Diwan AG et al ${ }^{6}$ and Madu AJ et al ${ }^{8}$ found positive $\mathrm{M}$ band in $82 \%, 100 \%$ and $90.5 \%$ respectively and we 
found in 90.91\%. Urine for Bence Jones was found by Dancaster CP et al ${ }^{12}$, Kyle RA et $\mathrm{al}^{5}$ and Madu AJ et al ${ }^{8}$ in $38 \%$, $16 \%$ and $48 \%$, but we found in only $14.3 \%$.

Kumar L et $\mathrm{al}^{7}$ found $6.4 \%, 12 \%$ and $81.7 \%$ patients in stage I, II and III, whereas Li SD et al ${ }^{16}$ found it to be $17.2 \%$, $47.5 \%$ and $35.5 \%$. Dimopoulos MA et al 15 found $29 \%, 38 \%$ and $33 \%$ in stage I, II and III and we found the same in $15.9 \%$, $45.45 \%$ and $38.64 \%$ respectively.

Despite the limitation of the study as regards the relatively small sample size and short duration of study, the results obtained in the study were a good indicator in respect to the clinical findings and laboratory profile of multiple myeloma.

\section{CONCLUSION}

We conclude that though most patients were in sixth decade, but we got significant involvement in younger age group. Bone pain, mostly low backache was the most common presenting symptom along with fatigue and weakness. Majority of patients were in higher stages (ISS II, III) at the time of diagnosis and severe anaemia, lytic lesions, pathological fractures and renal insufficiency were most observations in these patients in higher stages.

\section{REFERENCES}

1. Solly S. Remarks on the pathology of mollities ossium with cases. Med Chir Trans 1844;27:435-98.

2. Kyle RA. Multiple myeloma: an odyssey of discovery. Br J Haematol 2000;111(4):1035-44.

3. National cancer registry program: two year report of the population based cancer registries 1999-2000. New Delhi: ICMR 2005.

4. Palumbo A, Anderson K. Multiple myeloma. N Engl J Med 2011;364:1046-60.

5. Kyle RA, Morie GA, Witzig TE, et al. Review of 1027 patients with newly diagnosed multiple myeloma. Mayo Clinic Proc 2003;78(1):21-33.
6. Diwan AG, Gandhi SA, Krishna K, et al. Clinical profile of the spectrum of multiple myeloma in a teaching hospital. Med J DY Patil Univ 2014;7(2):185-8.

7. Kumar L, Vikram P, Kochupillai V, et al. Recent advances in the management of multiple myeloma. National Medical journal of India 2006;19(2).

8. Madu AJ, Ocheni S, Nwagha TA, et al. Multiple myeloma in Nigeria: an insight to the clinical, laboratory features and outcomes. Niger J Clin Pract 2014;17(2):212-7.

9. Rahaman AAU, Shah SZA, Devrajani BR, et al. International staging system: a tool to predict survival in patients with multiple myeloma. World Appl Sci J 2012;16(7):1004-8.

10. Durie BMG, Salmon SE. A clinical staging system for multiple myeloma, Correlation of measured myeloma cell mass with presenting clinical features, response to treatment, and survival. Cancer 1975;36(3):842-54.

11. Riccardi A, Gobbi PG, Ucci G, et al. Changing clinical presentation of multiple myeloma. EUR J Cancer 1991;27(11):1401-5.

12. Dancaster CP, Hussain OAN, Jackson WPU. Clinical features of multiple myeloma: a review of clinical manifestations and laboratory investigations in 40 cases. Postgrad Med J 1959;35(410):662-70.

13. Greipp P, Miguel SJ, Durie BG, et al. High serum levels of lactic dehydrogenase identify a high-grade lymphoma like myeloma. Ann Intern Med 1989;110(7):521-5.

14. Blade J, Rozman C, Cervantes F, et al. A new prognostic system for multiple myeloma based on easily available parameters. Br J Haematol 1989;72(4):507-11.

15. Dimopoulos MA, Kastritis E, et al. The International Scoring System (ISS) for multiple myeloma remains a robust prognostic tool independently of patients' renal function. Annals of Oncology 2012;23:722-9.

16. Li SD, Wang YF, Qi JY, et al. Indian J Haematol Blood Transfus. Springer 2010;26(3):83-8. 